bottom of the deep sea, two different deposits are in process of formation side by side, each characterised by a distinct Fauna, and yet apparently produced under perfectly similar conditions of land and sea, area, depth of water, \&c. On investigating this curious result, however, it was found that the temperature of the water circulating over these two areas is very different, and that this mere difference of temperature is capable of entirely changing the character of the fauna of the simultaneously formed deposits. Thus an entirely new element is brought into geological speculations, since it is shown that at one and the same time strata may be accumulated containing widely different organic remains. In addition to this, they have shown that the calcareous deposit known to us as chalk is now being deposited all over the bed of the Atlantic Ocean, and there are many weighty reasons for believing that this deposit has gone on steadily ever since the time during which we imagined the cretaceous rocks of the world to have begun and ended. Many organisms formerly supposed entirely extinct have been re-discovered in these deep-sea dredgings; and, in short, much has been done to show that our past geological reasoning requires thorough and careful revision. Prof. Gümbel's discovery of the existence of Bathybius and similar organisms at all depths, and stretching over an inclefinite period of geological time, is of the greatest importance in relation to this subject. Prof. Agassiz, on the other side of the Atlantic, has published reports of the deep-sea dredging off the Florida Coast, and has stated that the results of his researches, and those of others, both Englisir and Scandinavian, have convinced him that there is life all over the sea bottom, and that where evidence of marine life cannot be found, we are justified in calling in the agency of the sea to explain certain obscure facts. These conclusions cannot be without their important bearing on many commonly received geological theorles.*

In BOTANY many very careful series of observations have been made in the physiological department. Among the most important we may mention those of Prillieux and Duchartre in France, confirmed by Dr. $\mathrm{M}^{6} \mathrm{Nab}$ in this country, that, contrary to the previously accepted hypothesis, plants do not absorb any appreciable amount of aqueous vapour through their leaves; and those previously announced by $M$. Deherain, that the evaporation of water from the leaves of plants is due to sunlight rather than to heat, and proceeds independently of the degree of saturation of the atmosphere. Much attention has also been paid in Germany, Italy, and England, to the fertile field of the phenomena of fertilisation, opened out by $\mathrm{Mr}$. Darwin's observations.

In METEOROLOGY there is no great advance to chronicle. It still remains a Science without a head, a chaotic mass of facts with no definite order or arrangement; for though many are working at this subject, and some valuable papers on the Origin of Winds and Storms have been published, still no definite progiess can be ascertained.

The splendid appearances of the Aurora Borealis, visible all over the British Isles in September and October, have directed public attention to those unmistakeably magnetic phenomena, and to the connection which exists between

* During the past year all the most important papers on Deep-Sea Dredging have appeared in these columas, and we would refor otir readers to Vol. i. pp. $\times 35,106,267,6$ 1 2,657 ; Vol. ii. fp. $237,5 \pm 3$, \&.c. their appearance, great magnetical perturbations, and large solar spots. They have been examined very frequently during the past year by means of the spectroscope, and there is distinct evidence of lines in the green and red portion of the spectrum, the latter presumably due to hydrogen. We would direct attention to our desire to publish a complete tabular list of the more remarkable meteorological phenomena of the past year, so as to be serviceable to observers in all parts of the world. To render this as perfect as possible, we would invite the kind co-operation of all those interested in the subject who can forward us any data.

We cannot conclude without noticing how much Science has lost during the latter half of the year just encled by the fearful struggle that has taken place between France and Germany, where each nation has brought into requisition all the resources of Science only to inflict as much injury as possible on the other. For neariy six months we have witnessed the sad sight of workshops shut up, laboratories closed, universities and public schools wanting both professors and students, and the friendly emulation of similar tastes and pursuits turned to the fierce rivalry of the sword. Science will have to deplore the untimely loss of many of her most attached workers, and their country will have lost those who would in happier times have done her as much honour at home as they have shown bravery in the field. Whilst the French Academy, shut up in besieged Paris, has brought the art of ballooning to its present state of perfection, so that now it is used as a means of communication with the outside world, the result of the subtle strategy of the Germans, and the scientific education they so generally possess, has been to give them advantages which have, to the present time, baffed their adversaries.

J. P. E.

\section{THE INTELLIGENCE AND PERFECTIBILITY OF ANIMALS}

The Intelligence and Perfectibility of Animals from a Philosophic Ponnt of Vieze. With a few Letters on Man. By Charles Georges Leroy, partly under the pseudonym of "The Naturalist of Nuremberg." (London : Chapman and Hall, I870.)

7 HESE Essays, written nearly a century ago, seem to have been intended chiefly as an answer to the doctrines of those French philosophers who maintained that animals were merely animated machines, or, as it was expressed by Buffon, that "the animal is a purely material being, which neither thinks nor reflects, but which nevertheless acts," and that "the determining principle of the animal's actions proceeds from a purely mechanical infuence, absolutely dependent upon its organisation." Our author, on the contrary, maintains that the mental faculties of animals are strictly comparable with those of man; that they remember, combine, and reflect; that they are capable of self-improvement; and even that they possess a true language fully adapted to their needs. To support his views he gives what we may term a generalised life history of several animals, such as the wolf, fox, stag, fallow-deer, and roebuck, which his position of Ranger of Versailles and Marly gave him ample opportunities of studying. The chief fault of these interesting shetches is, that they detail bardly any 
of the special observation on which the generalised statements are founded. We are, therefore, unable to tell how much is fact and how much inference; and, what is probably the result of careful life-long observation fails to produce that effect of reality which a more direct narrative style would have given to it. $\ln$ a few cases, however, he gives us actual observations; as when he proves that animals can count, by stating the fact that in order to destroy crows, which were destructive to game, a hut was made at the foot of a tree where there was a nest, in order to shoot the old birds when they returned to their young. It was found, however, that after the first time the man was always watched into the hut, and the crows would not return till he had left it or till night. To deceive them two men went to the door of the watchhouse, one entering and the other passing on, but the crows would not come. The next day three went and two passed on, but still with no effect; and it was not till five or six went and all but one passed on, that they were deceived, being unable to count so many.

M. Leroy appears to reject altogether what is commonly termed Instinct, maintaining that the word should be applied only to those acts which are the direct consequences of organisation, such as the grazing of the stag, or the flesh-eating of the fox; but not to the expedients to which those animals resort in the gratification of their natural wants, which are due to sensation, observation, memory, and experience. To the objection that many animals perform complex operations perfectly well without experience, and always in the same manner, he replies that in many cases the fact is not so. He maintains, for instance, that there is a distinctly perceptible inferiority in the nests made by young birds, thus anticipating the observation of the American Wilson; and further remarks that the best constructed nests are formed by birds whose young remain a long time in them, and thus have more opportunity of seeing how they are made He says that the nests of young birds are ill-made and badly situated; and that the defects of these first constructions are remedied in time, when their builders have been instructed by their sense of the inconveniences they have endured. He maintains that nests of the same species of bird differ as much as human dwellings, and that of a hundred swallows' nests no two are exactly alike; and he imputes to want of long-continued observation our failure to discover improvement in them; a want which curiously enough, has been remedied by $M$. Pouchet, who has found a decided improvement in the nests of swallows at Rouen during lis own lifetime. Our author has also some excellent remarks on hereditary habit, as strikingly shown in the case of many of our sporting dogs, and which, he believes, in wild animals is often mistaken for instinct ; and he concludes that "It is possible that the actions which we see performed by some animals, independently of the teachings of experience, are the fruit of a knowledge of very ancient date, and that in former times a thousand trials, attended with more or less success, have finally led to the attainment of the degree of perfection which we see manifested in some of their works at the present day."

The migrations of birds, also, he maintains are the result of no blind instinct, but of instruction handed down from generation to generation. He says, "Let us take the swallows as an example which every one can observe. In the first place, their departure is always preceded by assemblages, the frequency and duration of which can leave no doubt that their object is to effect all the necessary preparations for a voyage undertaken by creatures who have the faculty of sensibility, and of understanding one another, and who are united for a common purpose. The incessant and varied twittering which reigns in these assemblies, clearly indicates communications and orders, indispensable for the numerous offspring of the year. They must stand in need of preliminary instruction, constantly repeated, to prepare them for the great event. Frequent trials of fight are no less indispensable, and are often followed by a repetition of previous lessons, which makes our roofs and chimneys ring again. Assemblies of men who should speak a foreign language could not give more evident signs of a similar project. But there is a more convincing proof than this analogy that these migrations are not the result of a blind and mechanical inclination. When, at the time fixed upon for the flight, which cannot, owing to weather, be retarded without compromising the welfare of the whole species, some, and even a large number of indviduals, are too young to follow the rest, they are left behind and remain in the country. But it is in vain that they reach maturity; the supposed atiraction towards a certain region dees not affect them, or too slightly to enable them to gratify it. They perish, the victims of their ignorance, and of the tardy birth which made them unable to follow their parents."

The letters on Nan, which are curiousiy mixed up with those on animals, are neither so interesting nor so well reasoned. Their object is mainly to deduce the complex phenomena of human existence from the two principles of "the love of ease" and "ennui," which being antagonistic, lead men to all kinds of expedients to secure the one or escape from the other. These, with sympathy, which he considers the pre-eminently human emotion, are inade to explain most of the facts of man's mental nature. The work is written throughout in a pleasing and simple style, and exhibits to us a loving student of nature who observed and thought for himself, and who, in many of his conceptions, was far in advance of the great philosophers of the last century, among whom he lived.

AlFRed R. WALlace

\section{OUR BOOK SHELF}

Use and Limit of the Imagination in Science. By Prof. Tyndall. (London: Longmans and $\mathrm{Co}$.)

THIS is a second edition of Dr. Tyndall's Discourse at the meeting of the British Association at Liverpool. To it is now appended his Address as president of Section A of the British Association at the Norwich meting. This was analysed by Dr. Clark Maxwell at a later meeting (see NATURE, Liverpool Meeting, Address to Section A). There is also added a short Essay from the Saturday Revicw, with the quaint title of "Earlier Thoughts," suggesting the irrepressible "Country Parson," A.K.H.B. Another curious addition is a selection of favourable, unfavourable, and often ridiculous critiques of various parts of his discourse; which reveal the existence of a strange state of things in the arcana of editorial dens.

One or two trenchant notes are appended to the Dis- 